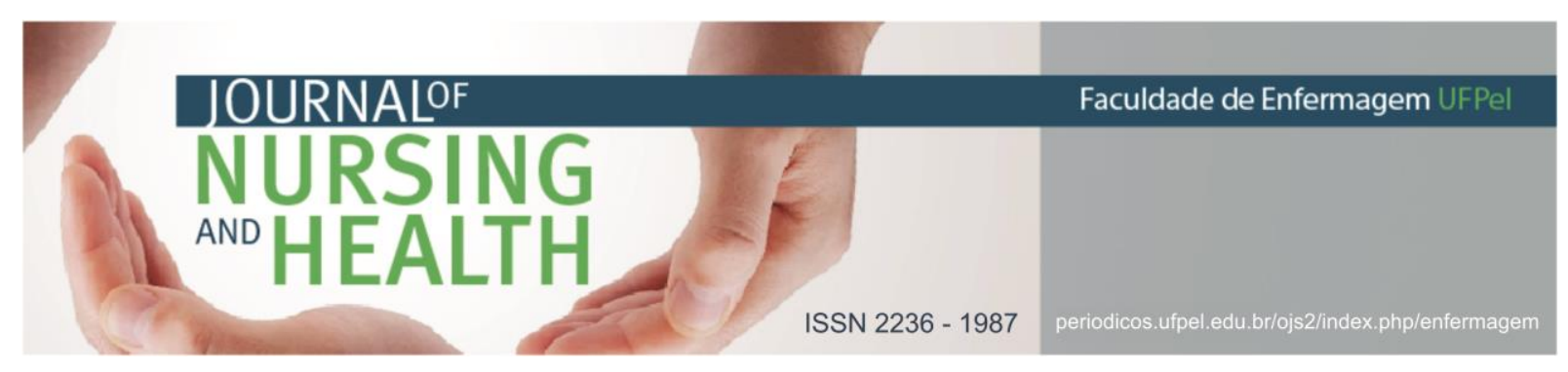

EDITORIAL

\title{
Ouvidores de vozes
}

Hearing voices

Escuchando voces

Olschowsky, Agnes ${ }^{1}$

Como citar este editorial: Olschowsky A. Ouvidores de vozes. J. nurs. health. 2018;8(n.esp.):e188401

Este número especial nos propõe a reflexão das nossas práticas em saúde mental que são feitas de múltiplas vozes, ou seja, para além de atualizarmos o conhecimento, temos aqui um texto que nos inquieta e nos interroga enquanto atores comprometidos com a "liberdade para cuidar".

Ouvir vozes essa é a temática deste número e, as narrativas, artigos e relatos de experiência apresentados, evidenciam a necessária interação permanente entre teoria e prática, sendo esse um pressuposto ético importante no processo de atenção psicossocial.

Inicialmente temos as entrevistas realizadas no primeiro Congresso Nacional de Ouvidores de Vozes no Brasil, realizado em 2017, que relatam as aproximações com grupos de ouvidores de vozes e as primeiras experiências no país.

Os artigos refletem sobre a experiência de ouvir vozes enquanto um evento vivido por muitas pessoas, apontando estratégias para um enfrentamento mais adequado a essa vivência.

O movimento dos ouvidores de vozes desponta como uma prática de resistência e, colocam a pessoa que ouve vozes como sujeito e protagonista do processo de cuidado, na qual os contextos socioculturais, históricos e políticos alicerçados na crítica aos saberes instituídos, nos mostra que é possível vivenciar de maneiras diferentes o enfrentamento e o alívio dos sofrimentos desse fenômeno.

Por fim, os relatos de experiência aguçam e indicam a importância de encorajar a falar sobre as vozes, apreender a conviver com elas e do engajamento das pessoas em movimentos reformistas para além da alucinação auditiva como sintoma psiquiátrico.

O texto nos intima a romper com conceitos aprisionadores da psiquiatria. É preciso resgatar um conceito mais positivo sobre saúde mental, sobre ouvir vozes, proporcionando aqueles que ouvem vozes todas as possibilidades para exercer sua

\footnotetext{
${ }^{1}$ Enfermeira. Doutora em Enfermagem Psiquiátrica. Professora Titular da Universidade Federal do Rio Grande do Sul (UFRGS). E-mail: agnes@enf.ufrgs.br http://orcid.org/0000-0003-1386-8477
} 
subjetividade, aumentando sua capacidade de escolha, de falar sobre si, sua história, cultura e sua vida.

Ter coragem, romper barreiras e reconhecer que ouvir vozes são novas cores e vozes das práticas reformistas na saúde mental.

Boa leitura!

Data de publicação: 19/09/2018 